\title{
Integration of EA and IT service to improve performance at higher education organizations
}

\author{
Agus Hermanto* and Supangat \\ Universitas 17 Agustus 1945 Surabaya, Informatics Departement, Semolowaru 45, Surabaya, Indonesia
}

\begin{abstract}
One of the perceived benefits of the use of information technology is the increased accuracy and speed of information that greatly helped the operations of an institution or organization. Politeknik XYZ as one of the organizations / institutions in the field of education, now need to consider the strategic role of information technology in supporting academic activities and develop a wide range of academic services, especially for students. Accordingly, in this study has been carried out the planning and improvement of information technology services in accordance with EA and IT Service standards, based on analysis using ACMM maturity level. The end result of architectural planning and service enhancement developed with TOGAF and ITIL is to be used as a reference in the improvement the role of information systems and technology in supporting business process organizations at Polytechnic XYZ. This study demonstrates the importance of raising awareness of the interdependent relationship between architecture and quality of service management in the organization of information technology.
\end{abstract}

\section{Introduction}

One of the perceived benefits of the use of information technology is the increased accuracy and speed of information that greatly helped the operations of the institution or organization. Therefore, it can be said with the increasing role of information technology will be directly proportional to the investment made. This will require careful planning in the implementation of information technology investment in the future, thus their governance requires good information technology within an organization, which starts from planning to implementation. Information technology governance has a lot of tools, such as TOGAF-ADM (The Open Group Architecture Enterprise-Architecture Development Method) and ITIL (IT Infrastructure Library), which is used as a guide in conducting the audit [1].

The appropriate use of TOGAF and ITIL in information technology governance can be obtained by analyzing and measuring the current state of an institution or organization in advance, so as to align the organization's business strategy and technology strategy to deliver maximum results for the organization. As in this study, the analysis and the measurement conditions at the Politeknik XYZ using ACMM (Architecture Capability Maturity Model), which has six levels and nine characteristics in assessing the maturity level of an organization [2].

Politeknik XYZ which is part of the national education system, at this time need to pay attention to the strategic role of information technology in supporting academic activities and develop a wide range of services and capabilities that can provide an edge over competitive pressure in regional markets to acquire new students. Accordingly, in this study will be carried out a gap analysis and architectural planning the development of information technology has been used by the Politeknik $\mathrm{XYZ}$ in order to determine the level of maturity so that the unknown levels of performance and effectiveness of information technology which has been running at the Politeknik XYZ based on standard TOGAF and ITIL.

\section{Theoretical Basis}

There is so much understanding of IT governance including IT governance is the responsibility of top management and management executives of an organization. It also explains that IT governance is part of organizational management as a whole consisting of leadership and organizational structure and the existing process is to ensure the continuity of IT organization and development of strategy and goals of the organization [3] [4]. Furthermore, in another definition says information technology governance is an organizational action undertaken by IT management to control the formulation and implementation of IT strategy and how to believe in business and IT itself, but also carries risks for the organization, resulting in a complexity of complexity, no high focus and operating and maintenance costs [5-7].

As John Zachman said that the increasing complexity in the application of information systems, it is necessary to use the architecture for the determination and control of interfaces and integration of all system components [8]. To achieve the organization's mission through the optimal performance of business processes with the efficiency of the IT environment, the application of EA should be

*Corresponding author: hermanto_if@untag-sby.ac.id 
incorporated into the roadmap of the organization. There are five focus areas for information technology governance: strategic alignment, value delivery, risk management, resource management, and performance measurement. In this research, we will use two standards at the same time that is TOGAF and ITIL. TOGAF is a framework developed by The Open Group's Architecture Framework in 1995. TOGAF is widely used in areas such as banking, manufacturing and education industries. One of the advantages of using this TOGAF framework is because it is a flexible and open source. TOGAF views enterprise architecture into four categories [2], as shown in Figure 1 below.

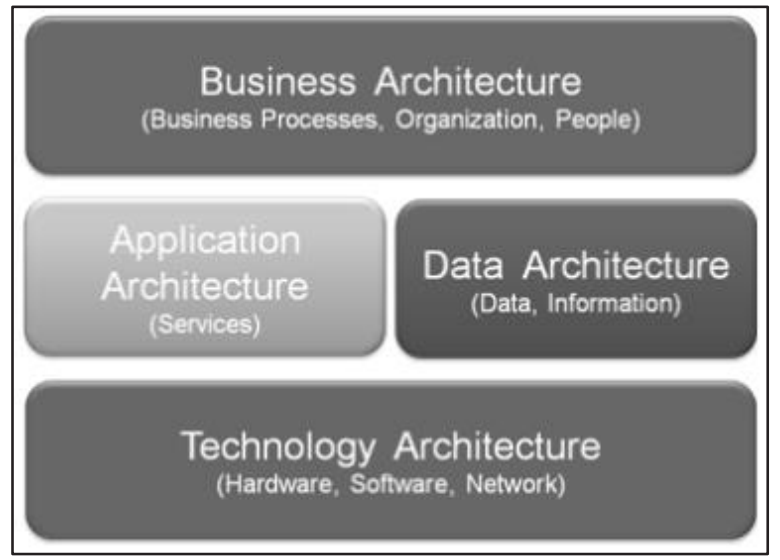

Fig 1. Categories Of Architrcture Domains In TOGAF

One form of deliverable from ADM is a recommendation of information technology-based service. Related to this, the framework used is ITIL which is the best practice of technology management information, and focuses on continuous measurement and improvement of quality information technology services, with several benefits, including: the first to adapt to business needs, the second is the efficiency in providing a well-defined service process, and the third is IT services that can be improved and measured [9-11].

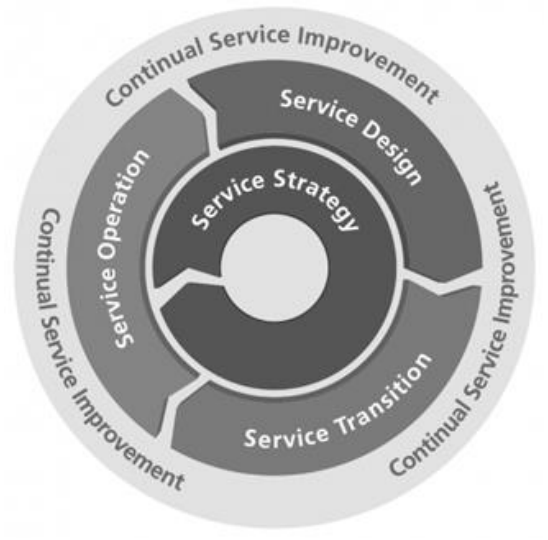

Fig 2. ITIL service life cycle diagram

\section{Previuos Research}

Based on the results of research conducted by Brian $\mathrm{H}$. Cameron and Eric McMillan, it was concluded that the most popular framework used in information technology governance is TOGAF by comparing various attributes or criteria for respondents in choosing the EA Framework, including: process completeness, ADM, interoperability or flexibility in using the elements, availability of architectural knowledge, neutrality, and alignment with industry standards (Cameron \& McMillan, 2013). In another study, various categories have been introduced for design patterns as a way to capture and re-analyze, design and apply well applied to the TOGAF framework, as well as provide motivational examples of how design patterns can be structured to create TOGAF framework architecture is generic and to improve the organization's performance in terms of IT services include the utilization of CSF that has been successfully identified in implementing ITIL [12-16].

\section{Scope and Research Method}

In this study, we conducted a literature study to get the relevant concepts on the problems encountered. We then conducted observations and interviews with stakeholders to get an overview of the conditions of the organization. We also developed questionnaires to conduct assessments to obtain technological maturity levels with reference to ACMM. Based on the ACMM analysis, we designed the information technology architecture using TOGAF, then integrated and mapped the architecture with ITIL. In Figure 3 below, we demonstrate the TOGAF and ITIL research and integration sequences, from key business processes to delivering and maintaining the IT services shown in Figure 2. The limitations of this study are the mapping of preliminary phase and phase A to service strategy, and phase A with requirement management to service design.

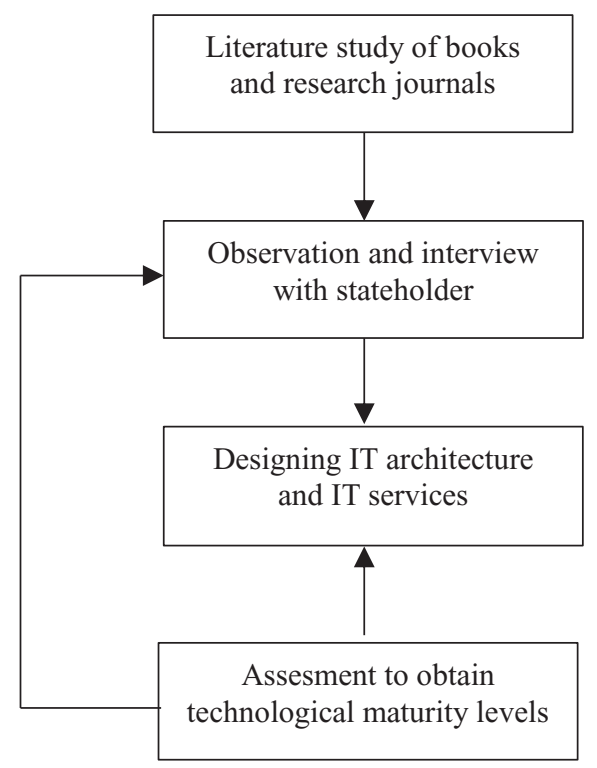

Fig 3. Overall research flow 
The integration of TOGAF and ITIL is quite necessary in this case because the business architecture is supported by TOGAF, but not by ITIL and IT services are handled by ITIL but not by TOGAF. While other elements (information architecture, technology architecture and IT solutions) are covered in both frameworks, although the level of detail is different for each framework.

\section{Result and Discussion}

As explained in the research methodology section, we conducted an assessment by preparing a questionnaire drawn from ACMM and we assigned to various levels of XYZ Polytechnic management to answer questions in the questionnaire. From the results of the questionnaire can be known condition of maturity level as shown in Figure 5 , it can be seen that the level of maturity of Polytechnic $\mathrm{XYZ}$ is very low, due to the large gap in all indicators. Based on CMM score card that has 12 indicators, there is only one indicator that reaches level one (initial), namely IT Security (indicator 10), while other indicators are still at level 0 (none) with maturity level measurement score is currently at 0.11 from 2.04 (expected maturity level score). The 12 indicators in ACMM are: Architecture process, Architecture development, Business linkage, Senior management involvement, Operating unit participation (two sub-indicators), Architecture communication (three sub-indicators), IT security, Architecture governance, IT investment and acquisition strategy. It shows that organizational management does not have awareness in information technology governance, so it can be said that business processes that occur in organizations have low efficiency and effectiveness.

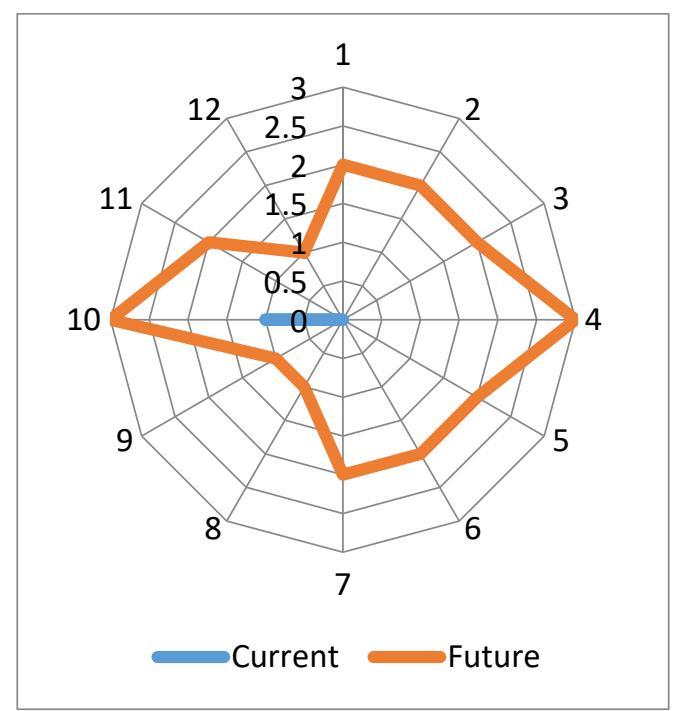

Fig 4. Assessment results in maturity level

In ITIL mentioned that IT Service Design is part of the whole process of business change. Services Design definition that refers to Figure 5, it can be even more clearly emphasize that ITIL and TOGAF can do integration (in a friendly way) in their respective areas (Sante \& Ermers, 2009), to be: the design of the service is an appropriate and innovative design on the IT-based Services, including architectural design, development process, policy analysis, and documentation, in accordance with current and future agreements. The assessment and analysis results for each phase of TOGAF will be mapped to ITIL, with the following description:

\subsection{The Preliminary and Phase A are Mapped to the Service Strategy}

Preliminary phase is used to determine the scope of enterprise architecture (EA) to be developed, determine commitment with management in EA development and conduct assessment using EA-CMM to know current governance and expected governance, using value chain analysis, while the phase A (Architecture Vision) is creating uniformity of views on the importance of EA to achieve organizational goals formulated in the form of strategy and determine the scope of the architecture to be developed, by making the concept of the solution diagram. Furthermore, the value chain and the concept of solution will be input on the service strategy, as shown in table 1 .

Table 1. Value chain diagram and the concept of solution mapped to the service strategy.

\begin{tabular}{|c|c|c|c|c|}
\hline \multicolumn{5}{|c|}{ Activities } \\
\hline \multirow{8}{*}{ 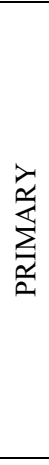 } & $\begin{array}{l}\text { Inbound } \\
\text { Logistics }\end{array}$ & $\begin{array}{l}\text { Student } \\
\text { Registration } \\
\text { \& transfer }\end{array}$ & $\begin{array}{l}\text { E- } \\
\text { Registration }\end{array}$ & \multirow{13}{*}{$\begin{array}{l}\text { Strategy } \\
\text { Managem } \\
\text { ent for IT } \\
\text { Services, } \\
\text { Service } \\
\text { Portfolio } \\
\text { Managem } \\
\text { ent, } \\
\text { Financial } \\
\text { Managem } \\
\text { ent for IT } \\
\text { Services, } \\
\text { Demand } \\
\text { Managem } \\
\text { ent, } \\
\text { Business } \\
\text { Relationsh } \\
\text { ip } \\
\text { Managem } \\
\text { ent }\end{array}$} \\
\hline & \multirow[t]{4}{*}{ Operation } & Lectures & E-Learning & \\
\hline & & Exam & E-Learning & \\
\hline & & Internship & E-Message & \\
\hline & & Final project & E-Learning & \\
\hline & $\begin{array}{l}\text { Outbond } \\
\text { Logistic }\end{array}$ & $\begin{array}{l}\text { Yudisium \& } \\
\text { Graduation }\end{array}$ & E-Message & \\
\hline & Marketing & Promotion & Web Portal & \\
\hline & Services & $\begin{array}{l}\text { Academic } \\
\text { services }\end{array}$ & $\begin{array}{l}\text { E-Scheduler } \\
\text { \& E- } \\
\text { StudyPro }\end{array}$ & \\
\hline & Firm & Financial & E-Payments & \\
\hline & $\begin{array}{l}\text { infrastruc } \\
\text { ture }\end{array}$ & Libraries & E-library & \\
\hline & $\begin{array}{l}\text { Human } \\
\text { Resource } \\
\text { Manage } \\
\text { ment }\end{array}$ & $\begin{array}{l}\text { Staffing } \\
\text { (Lecturers \& } \\
\text { Staff) }\end{array}$ & $\begin{array}{l}\text { E-Attendan } \\
\text { ce }\end{array}$ & \\
\hline & $\begin{array}{l}\text { Technolo } \\
\text { gy } \\
\text { Develop } \\
\text { ment }\end{array}$ & $\begin{array}{l}\text { Computer } \\
\text { lab }\end{array}$ & E-Labs & \\
\hline & $\begin{array}{l}\text { Procure } \\
\text { ment }\end{array}$ & $\begin{array}{l}\text { Facilities \& } \\
\text { infrastruc } \\
\text { ture }\end{array}$ & $\begin{array}{l}\text { E-Procure } \\
\text { ment }\end{array}$ & \\
\hline
\end{tabular}

\subsection{Phase A and Requirement Management are Mapped to the Service Design}

Requirement management aims to provide the process of managing architectural needs throughout the phase of the ADM cycle. This stage identifies the organization's core business, organizational issues and conceptualizes business solution concept solutions and information system solution concepts (SI) based on current 
organizational issues. Furthermore, the solution concept in phase A and the IS solution are mapped to the service design, as shown in Table 2.

Basically, the service strategy is to determine the strategy to serve the customer, with the first step is the assessment of customer and market needs, so that the explanation of the mapping process of value chain analysis and architectural vision, tailored to the main process contained in service strategy, while the requirement managament and architectural vision mapped to service design to develop effective and efficient service solutions that meet current business needs as well as IT needs, derived from service strategy. In Service Design, there are five aspects that must be integrated to ensure that the integrated enterprise architecture that is produced consists of a satisfactory set of standards, design and architecture, all the management and operational requirements of the service, as well as the functionality required by the business.

Table 2. The concept of solution and requirement management mapped to the service design.

\begin{tabular}{|c|c|c|}
\hline $\begin{array}{c}\text { Concept of } \\
\text { Solution }\end{array}$ & IS Solution & Service Design \\
\hline E-Learning & \multirow{4}{*}{ Academic-IS } & \multirow{12}{*}{$\begin{array}{l}\text { - Design } \\
\text { Coordination } \\
\text { - Service Catalogue } \\
\text { Management } \\
\text { - Service Level } \\
\text { Management } \\
\text { - Availability } \\
\text { Management } \\
\text { - Capacity } \\
\text { Management } \\
\text { - IT Service } \\
\text { Continuity } \\
\text { Management } \\
\text { - Information } \\
\text { Security } \\
\text { Management } \\
\text { - Supplier } \\
\text { Management }\end{array}$} \\
\hline E-Scheduling & & \\
\hline E-StudyPro & & \\
\hline E-Labs & & \\
\hline E-Message & \multirow{4}{*}{ Student-IS } & \\
\hline E-Registration & & \\
\hline E-library & & \\
\hline E-Payments & & \\
\hline E-Budgeting & & \\
\hline E-Attendance & & \\
\hline Web Portal & & \\
\hline E-Procurement & $\begin{array}{l}\text { Administration- } \\
\text { IS }\end{array}$ & \\
\hline
\end{tabular}

Combining ITIL in the TOGAF context provides a toolkit to convey the vision that XYZ Polytechnic has an opportunity to align their services and achieve alignment of business and technology objectives. This is because ITIL provides a framework that guides organizations in delivering IT services. On the other hand, TOGAF provides methodologies and frameworks that guide Business and IT stakeholders to transform IT throughout the organization. As shown in Tables 1 and 2, the process of developing the concept of solutions can be done simultaneously using both TOGAF and ITIL frameworks. The report in this study is just the first step in integrating the two frameworks to reduce duplication of activities in IT development.

\section{Conclusion}

Combining ITIL in the TOGAF context provides a toolkit to convey the vision that XYZ Polytechnic has an opportunity to align their services and achieve alignment of business and technology objectives. This is because ITIL provides a framework that guides organizations in delivering IT services. On the other hand, TOGAF provides methodologies and frameworks that guide Business and IT stakeholders to transform IT throughout the organization. As shown in Tables 1 and 2, the process of developing the concept of solutions can be done simultaneously using both TOGAF and ITIL frameworks. The report in this study is just the first step in integrating the two frameworks to reduce duplication of activities in IT development.

However, this research has shown that by integrating EA and IT service management provides benefits to the organization in the form of alignment of vision, mission and objectives of the organization in setting up IT development to support the organization's progress and consideration in preparing its resources

\section{References}

1. T. v. Sante and J. Ermers, Whitepaper, OGC Pub., (2009).

2. The Open Group, TOGAF, TOG Pub., (2011).

3. ITGI, IT Gov. Imp. Guide, ITGI, (2007).

4. P. Weill and J. W. Ross, IT Gov.., MIT, (2004).

5. W. Grembergen, Stra. for IT Gov., Idea Group, Inc., (2003).

6. W. V. Grembergen, S. D. Haes dan E. Guldentops, Struct., Proc. and Rel.Mech. For IT Gov, Idea Group Publishing, (2004).

7. R. R. Peterson, Integ. Strat. and Tactics for IT Gov, Strat for IT Gov., Idea Group Inc. , 37 (2004)

8. J. Zachman, A Framework for Inf. Syst. Arc, IBM Systems Journal, (1987).

9. ITGI, ITIL for ITSM, 26 March 2017. [Online]. Available: https://www.itgovernance.co.uk/itil

10. Cab. Office, ITIL Best Practise Manag., TSO, 2011.

11. S. Kempter and D. A. Kempter, IT Process WIKI, 26 March 2017. [Online]. Available: http://wiki.en.itprocessmaps.com/index.php/Main_Page

12. M. Taleb and O. Cherkaoui, Pattern-Oriented Approach for EA, Journal of Software Engineering and Applications, 45 (2012).

13. J. Lussem and H. Harrach, AICCS), (2013).

14. N. Ahmad and Z. M. Shamsudin, Information Technology and Quantitative Management, 237 (2013).

15. J. Iden and T. R. Eikebrokk, International Journal of Information Management, 512 (2013).

16. J. N. Cruz-Hinojosa dan J. A. Gutiérrez-de-Mesa, Computer Standards \& Interfaces, 124 (2016).

17. TOGAF, "TOGAF Online $>$ Part I: Introduction $>$ Core Concepts," 10 March 2017. [Online]. Available: http://www.togaf.info/togaf9/chap02.html

18. B. H. Cameron and E. McMillan, Journal of Enterprise Architecture, 60 (2013). 